\title{
PL・PS 補強盛土の長期社測結果と圧縮量の予測
}

\author{
東京大学工学部 \\ 内村太郎・M. S. A. Siddiquee・龍岡文夫 \\ 鉄道総合技術研究所 \\ 舘山 勝
}

プレローディド・プレストレスト（P L ・ P S ）補強土工法は、プレロードとプレストレスによって 補強盛土の剛性を飛䘣的に高め、より大きな荷重を受ける構造物にも応用できるようにする工法である。 1996年夏に、J R九州篠栗線馬出橋梁で、実施工の P L・P S 補強土橋脚が建設され、1 年後の1997年 から供用開始された。建設時から 4 年にわたり挙動の連続計測を行い、P L・P S 補強土構造物の長期 的な安定性を確かめた。

P L・P S 構造物の長期的な性能は、盛土材や補強材のクリープ・リラクゼーション・絽返し载荷に よる変形特性が決定的な要因になると考えられる。それらの挙動を予測するモデルの開発は、P L ・ P $\mathrm{S}$ 構造物の設計法を確立するために大きく役立つ。本報では、三要素型のレオロジーモデルである New Isotach モデルを用いて、P L・P S 橋脚へのプレロード時の荷重・変形特性の解析を試みた。 キーワード：補強盛土、プレロード、プレストレス、変形、時間勃果

\section{Observation and Estimation of Long-term Performance of Preloaded and Prestressed Geosynthetic-Reinforced Soil Structure}

T. Uchimura, M.S.A.Siddiquee and F.Tatsuoka : Department of Civil Engineering, University of Tokyo M. Tateyama : Railway Technical Research Institute

Vertical preloading and prestressing (PLPS) of geosynthetic-reinforced soil structure aims at substantially increasing its stiffness and decreasing the residual settlement. The first prototype PLPS reinforced soil pier was constructed for a railway in 1996, and has been open to service for more than three years. Long-term measurements for more than four years have been made. It has been proven that PLPS structures are very stable for a long-term of service.

The rheological characteristics such as creep and relaxation, and the residual deformation under cyclic loading of the backfill soil and reinforcement are considered to be important factors affecting the long-term behaviour of PLPS structures. The development of theoretical models of those behaviours is essential for developing the relevant design procedure of PLPS structures. In this paper, one of three-component rheology models, named "New Isotach Model", is used to analyze the observed load-deformation behaviour of the PLPS pier during its preloading procedure.

Keywords: Reinforced soil embankment, Preload, Prestress, Deformation, Time effect 


\title{
P L・PS 補強盛土の長期計測結果と圧縮量の予測
}

\author{
東京大学工学部 \\ 鉄道総合技術研究所 \\ 内村太郎・M.S. A. Siddiquee ・龍岡文夫 \\ 舘山 勝
}

\section{1.はじめに}

プレローディド・プレストレスト（P L ・ P S ） 補強土工法は、プレロードとプレストレスによって 補強盛土の剛性を飛躍的に高め、また残留変形を決定的に小さくして、大きな荷重を受けてかつ許容変 形量の小さな構造物（橋台、橋脚、重要構造物の基蓬など）にも応用できるようにする工法である。

土は延性的なので、基礎地盤の変形にも致命的な破壤をせず柔軟に追従でき、杭基䃈を省略できる。 また現場発生土を利用できればさらにコストを抑えられる。このような場合には、従来の鉄筋コンクリ 一ト（R C）構造に比べ、かなり安価で合理的な構造物ができる。

1996年夏に、J R九州篠栗線馬出橋梁で実施工の P L・P S 補強土橋脚が仮設構造物として建設され、 翌年1997年から供用開始された（図 1 のP 1 ）。その举動の約 4 年間にわたる計測結果を報告する。ま た、この橋脚のプレロード時の荷重・変形挙動を、New Isotach モデルを用いて解析した。

\section{P L・P S 補強土橋脚の概要と長期計測結果}

図 2 に、P L ・ P S 橋脚 P 1 の構造を示す。橋脚の設計桁荷重は $197 \mathrm{kN}=20.1 \mathrm{tf}$ 、設計列車荷重は 衝撃荷重を含めて $1330 \mathrm{kN}=136 \mathrm{tf}$ である。基礎地盤は厚さ $11 \mathrm{~m}$ の軟弱粘土層であり、セメント混合 で改良した。さらに、地表面から深さ $1 \mathrm{~m}$ までは、地盤改良杭を密に打設し、下部反力板を形成した。 地盤改良杭に、 4 本の P C 鋼棒（直径 $35 \mathrm{~mm}$ ）を約 $4 \mathrm{~m}$ 挿入して定着し、タイロッドとした。補強土部 分は、4 辺にレキの入った土のうを積み上げてジオグリッドで巻き込みながら構築した。盛土材は粒度 調整砕石 $\left(\mathrm{D}_{\max }=30 \mathrm{~mm}, \mathrm{D}_{50}=0.9 \mathrm{~mm}, \mathrm{Uc}=16.5\right)$ 、補強材はポリマーのジオグリッドである。ジオグリッドは、 向かい合う 2 壁面ごとにそれぞれ $30 \mathrm{~cm}$ 間隔で敷設したため、全体で平均 $15 \mathrm{~cm}$ となっている。盛土天 端に R C 小橋台（厚さ $80 \mathrm{~cm}$ ）を構築し、これを上部反力板とした。

タイロッド上端にそれぞれ油圧ジャッキを設置し、上部反力板で反カをとってタイロッドに張力をか けることで、橋脚を鉛直方向に圧縮した（プレロード：図 3 ）。1 日目に、2350kN = $240 \mathrm{tf}$ のプレロ ードを加えた後（図 $3 \mathrm{~A}$ ）、およそ 2 週間の工程（現場の要請により平日の昼間のみ载荷したので、実 質は72時間）でクリープ圧縮させてから（図 $3 \mathrm{~B}$ ）、タイロッドの張力を $950 \mathrm{kN}=97 \mathrm{tf}$ に除荷した（図 $3 \mathrm{C} ）$ 。その直後にタイロッドと反力板とをナットで固定した。これ以後は、950kN のタイロッド張力 がかかった状態になり、これが供用時にプレストレスとして常に盛土を鉛直方向に圧縮する（図 $3 \mathrm{D} ） 。$ プレロード中の盛土の鉛直圧縮量は最大 $8 \mathrm{~mm} ゙$ あ、また 1080 2350kN で除荷・再載荷した時の弾 性的変形は $0.5 \mathrm{~mm}$ （図 $3 \mathrm{C}$ ） で、非常に剛性が高かった。プレロード載荷、プレストレスの導入の後、 4 壁面に厚さ $30 \mathrm{~cm}$ の R C 剛壁面を打設した。

このあと、桁荷重を設置し、約 1 年後の 1997 年 8 月に供用開始した。それ以降、 1 両 40 卜ン前後の車 両が $1 \sim 6$ 両編成で 1 日 120 回以上通過している。 

A1
P1
A2
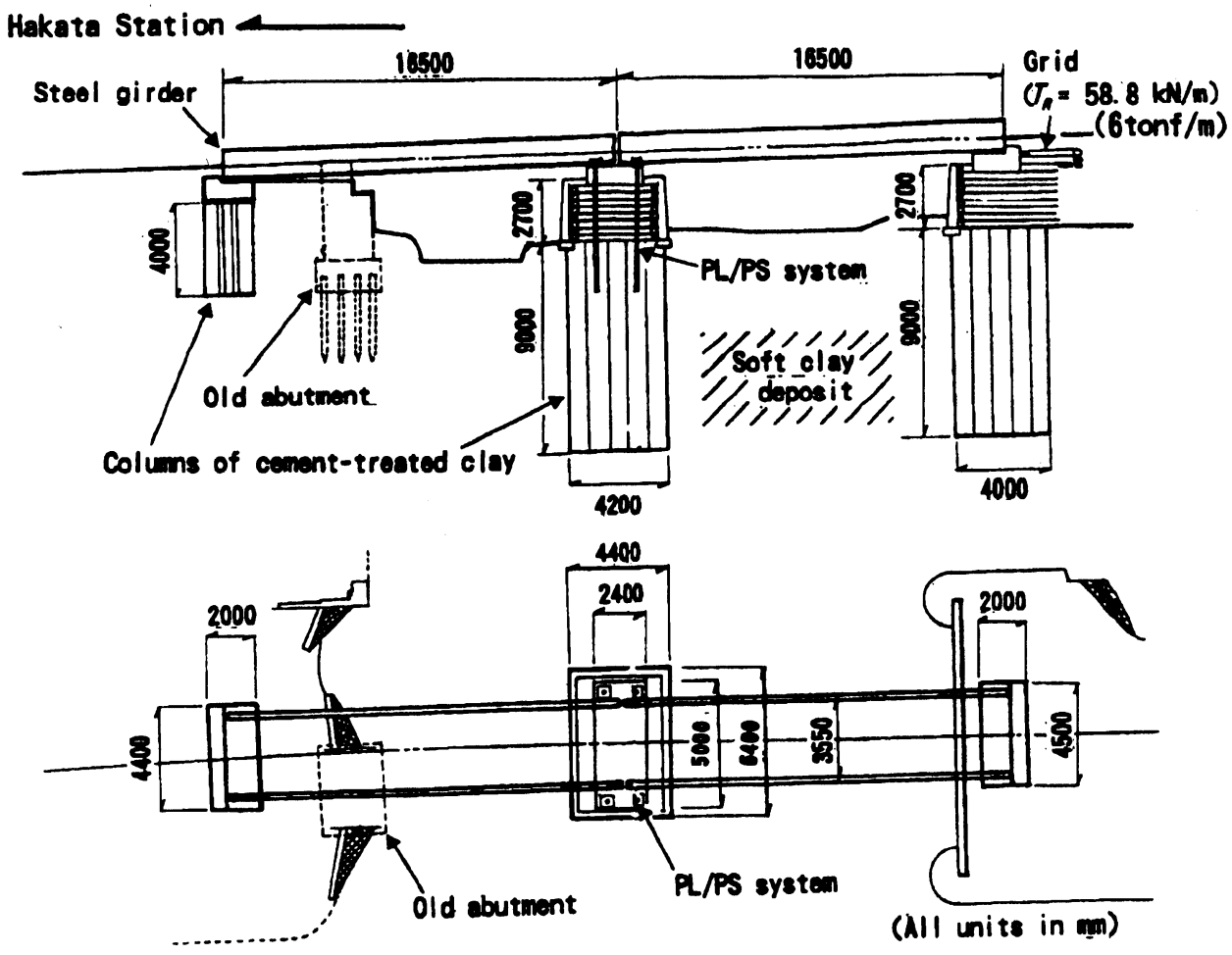

図 1 J R 九州篠栗線馬出橋梁の全体図

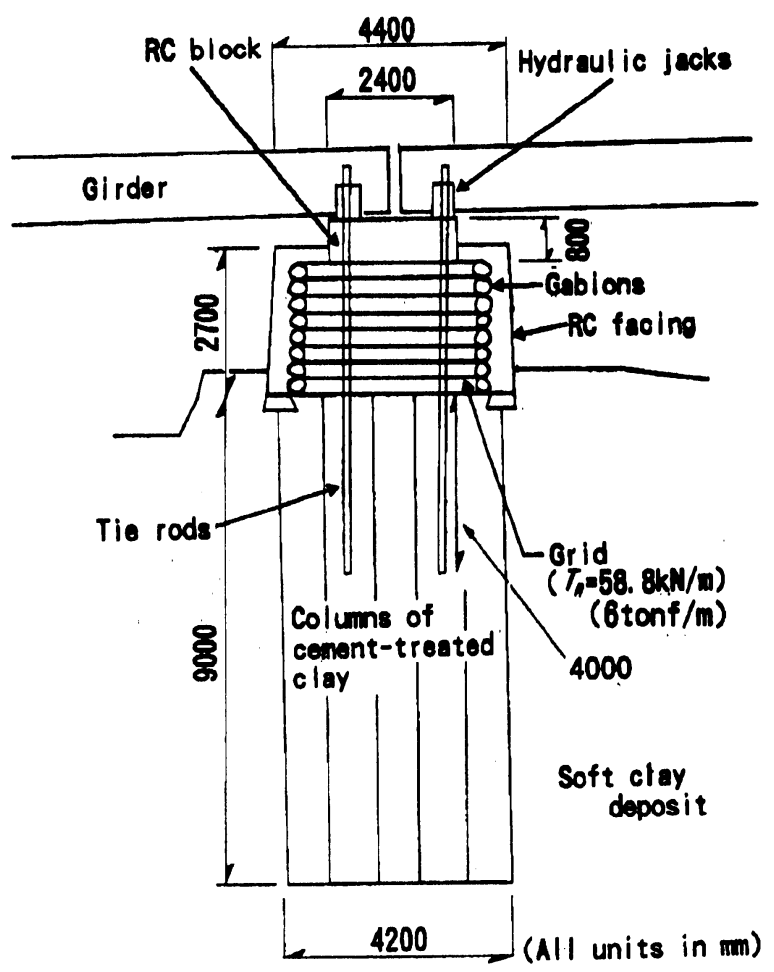

図 2 P L ・ P S 橋脚 P 1 の構造図

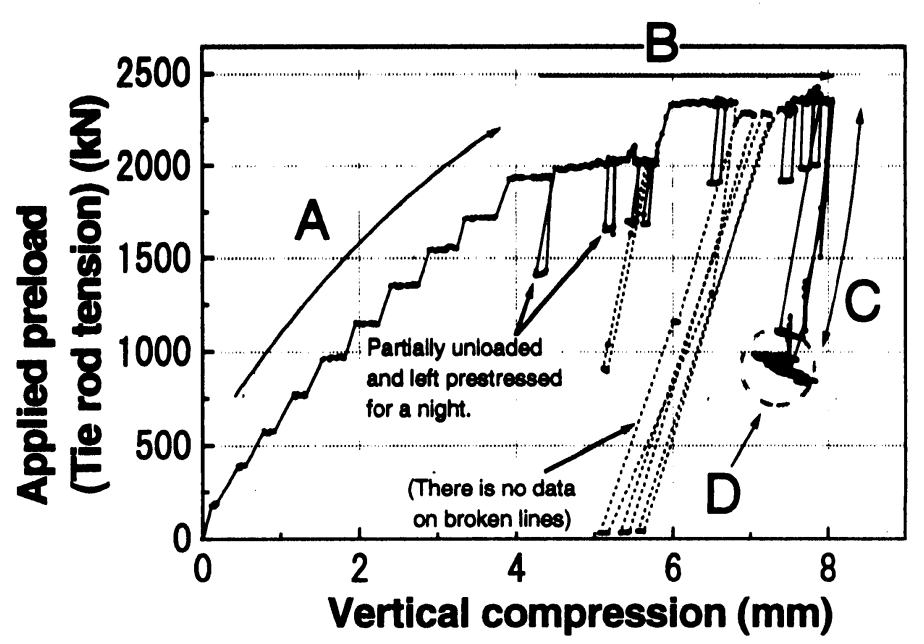

図 3 プレロード(タイロッド張力) と盛土の圧縮量の関倸 
P L ・ P S 補強土工法では、(1)高いプレロードにより予め盛土材に十分なクリープ変形をさせた後に 除荷する事で、それ以上のクリープ・塑性変形が起こりにくくなる。(2)常に高いプレストレ゙スで圧縮さ れていることで、盛土材のヤング率が高まる。(3)プレロードによって補強材に入った張力が、プレスト レス状態でも残留して盛土の変形を抑制する、という作用が倒いていると考えられる。

図 4 は、建設時のプレロード载荷を含む約 4 年間のP L・P S 橋脚のタイロッド張力（う盛土への静 的鋁直荷重）と鉛直圧縮量である。温度変化によると思われる 1 年周期の変動を無視して長期的な変化 速度を読みとると、P L・P S 橋脚はプレロード時に $8 \mathrm{~mm}$ 圧縮した後は $0.25 \mathrm{~mm} /$ 年の速さで圧縮し、 それに伴ってタイロッドの張力が $51 \mathrm{kN} /$ 年で減少している。供用開始前後で、盛土の圧縮速度、タイロ ッド張力の減少速度に顕著な変化はなく、交通荷重の練返し载荷に対しても大きな残留変形を起こすこ とがない。一方、図4 には、同じ橋梁でプレロード、プレストレスをかけていない補强土檽台（図 1 の A 2 ) の鉛直圧縮量も比較のために示し ているが、供用開始前から自重と桁荷重 によってクリープ圧縮しており、さらに 供用開始後は交通荷重の絽返し载荷によ って大きな残留圧縮が進行し、3 年経過 した現在も続いている。この圧縮量は、 橋脚 P 1 がプレロードによって圧縮した 量をはるかに超える。

これらの計測結果から、P L・P S 構 造物が長期的に非常に安定しており、絽 返し荷重に対しても残留変形がほとんど 起こらないことが分かる。

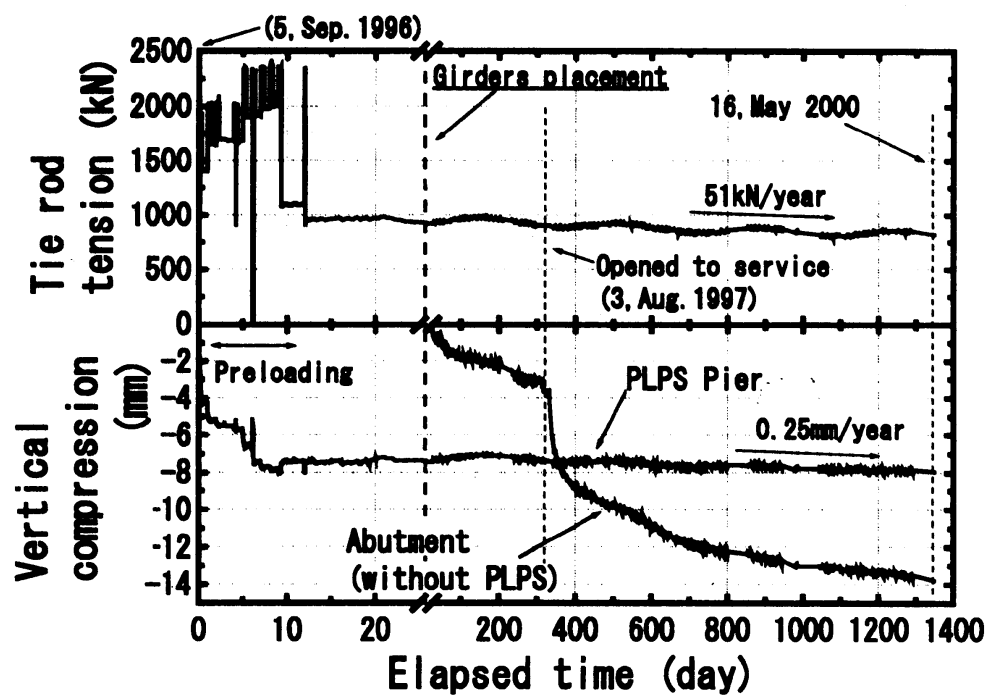

図 4 タイロッド張力および橋脚・橋台の圧縮量の経時変化

\section{3.プレロード酨荷時の荷重・圧縮特性の解析}

3. 1 New Isotach モデルの概要

前節で述べたような、P L・P S 補強土橋脚の優れた長期安定性は、プレロード時に十分クリープ変 形させて除荷したこと、常に高いプレストレスで盛土材を圧縮していることによると思われる。盛土の クリープ圧縮やリラクゼーションによってプレストレスが低下すると、盛土材のヤング率が低下するた めに交通荷重によるひずみ振幅が大きくなり、塑性変形が生じて残留変形が累積し、さらにプレストレ スが低下するという悪循環に陷る可能性がある。そのため、プレストレスを長期間にわたって一定水準 以上に保つことが必要である。このように、P L ・P S 構造物では、長時間の静的・動的荷重に対する 特性、すなわち時間依存特性が重要であり、設計においても考虑する必要がある。今後、盛土材と補強 材の時間依存特性のモデル化が必要だが、ここでは手始めとして、プレロード時の荷重・時間・圧縮の 関係（図 3 のA）に限定して、龍岡ら (文林4)が提唱する New Isotach モデルの適用を試みた。

Isotach 特性とは「いかなる時も、ひずみとひずみ速度と応力の関係が一意に決まる」という性質で ある。これを改良した New Isotach モデルは、古くからある三要素型レオロジーモデルの一種である。 
図 5 に概念図を示す。全体のひずみ $\varepsilon$ は、図 5 a の要素 (A)の弾性ひずみ $\boldsymbol{\varepsilon}^{e}$ と、要素 (B), (C) の不可逆ひ ずみ $\varepsilon^{i r}$ の和として表される（図 $5 \mathrm{~b}$ 参照）。つまり、

$$
\varepsilon=\varepsilon^{e}+\varepsilon^{i r}
$$

要素 (A) は非線形弾性体であり、既存の経跧則に従って次式の応力依存性を仮定した(文献)。

$$
\frac{d \sigma}{d \varepsilon^{e}}=E_{0}\left(\frac{\sigma}{\sigma_{0}}\right)^{m} \quad \begin{gathered}
\text { (但し、 } \mathrm{d} \sigma: \text { 応力増分、 } \mathrm{d} \varepsilon \cdot \text { 弾性ひずみ增分、 } \sigma_{0} \text { :基淮応力、 } \\
\left.\mathrm{E}_{0}: \sigma=\sigma_{0} \text { の時の } \mathrm{d} \sigma / \mathrm{d} \varepsilon \cdot \mathrm{m}: \text { 定数 }\right)
\end{gathered}
$$

また図 $5 \mathrm{a}$ の全体の応力 $\sigma$ は、要素 (B) の時間非依存の応力 $\sigma^{\mathrm{f}}$ と要素 (C) の時間依存の応力 $\sigma^{v}$ とに分 配される（図 $5 \mathrm{c}$ 参照）。つまり、

$$
\sigma=\sigma^{\mathrm{f}}+\sigma^{\mathrm{v}}
$$

要素 (B) の応力 $\sigma^{\mathrm{f}}$ は不可逆ひずみ $\varepsilon^{i r}$ の関数であり、不可逆ひずみ速度 $\boldsymbol{\varepsilon}^{i r}$ には依存しない。ただし、 䋘返し载荷が行われる場合は、その载荷展歴には依存する。関数 $\sigma^{\mathrm{f}}\left(\boldsymbol{\varepsilon}^{i r}\right)$ の一般的な形は現在のところ 不明で、材料ごとに実験結果などからそのつど関数を与える必要がある。一方、要素 (C) の応力 ${ }^{v}$ は不 可逆ひずみ $\varepsilon^{i r}$ と不可逆ひずみ速度 $\dot{\varepsilon}^{i r}$ の関数で、これがモデルの速度依存性を決定する。 $\sigma^{\vee}\left(\varepsilon^{i r}, \dot{\varepsilon}^{i r}\right)$ については、龍岡ら (文触) にならって、次の関数型を仮定した。

$$
\begin{aligned}
& \sigma^{\mathrm{v}}\left(\varepsilon^{i r}, \dot{\varepsilon}^{i r}\right)=\sigma^{\mathrm{f}}\left(\varepsilon^{i r}\right) \cdot \mathrm{g}_{\mathrm{v}}\left(\dot{\varepsilon}^{i r}\right) \quad \text { ただし、践 }\left(\dot{\varepsilon}^{i r}\right)=\alpha\left[1-\exp \left\{1-\left(\frac{\dot{\varepsilon}^{i r}}{\dot{\varepsilon}_{\text {ref }}^{i r}}+1\right)^{m}\right\}\right] \\
& \text { よって、 } \sigma=\sigma^{\mathrm{f}}\left(\varepsilon^{i r}\right)+\sigma^{\mathrm{v}}\left(\varepsilon^{i r}, \dot{\varepsilon}^{i r}\right)=\sigma^{\mathrm{f}}\left(\varepsilon^{i r}\right) \cdot\left\{1+\mathrm{g}_{\mathrm{v}}\left(\dot{\varepsilon}^{i r}\right)\right\}
\end{aligned}
$$$$
\text { ここに、 } \alpha 、 m 、 \dot{\varepsilon}_{r e f}^{i r} \text { は、それぞれ定数 }
$$
である。 $\alpha$ は不可逆ひずみ速度依存性 $\mathrm{g}_{\mathrm{v}}\left(\dot{\varepsilon}^{i r}\right)$ のスケールを、 $\dot{\varepsilon}_{\text {ref }}^{\text {ir }}$ は(時間) $)^{-1}$ の次元 を持ち不可逆ひずみ速度のスケールを決め る。式 4 に $\sigma^{\mathrm{f}}\left(\varepsilon^{i r}\right)$ が含まれるので、要素 (B) と要素 (C) は独立ではない。 $\mathrm{g}_{\mathrm{v}}\left(\dot{\boldsymbol{\varepsilon}}^{\mathrm{ir}}\right)$ は、 $\dot{\varepsilon}^{i r}=0$ のとき $0 、 \dot{\varepsilon}^{i r}=+\infty$ のとき $\alpha$ となる 単調増加関数である。このモデルでは、不 可逆ひずみ速度が非常に小さい準静的载荷 では応力ひずみ関係が $\sigma=\sigma^{\mathrm{f}}\left(\boldsymbol{\varepsilon}^{i r}\right)$ になる。 $\dot{\varepsilon}^{i r}>0$ の場合には、不可逆ひずみ速度が高 いほど $\sigma$ が増加し、非常に高速なときは $\sigma$ $=(1+\alpha) \sigma^{\mathrm{f}}\left(\varepsilon^{i r}\right)$ となる。応力ひずみ関係は $\sigma=\sigma^{\mathrm{f}}\left(\varepsilon^{i r}\right)$ と $\sigma=(1+\alpha) \sigma^{\mathrm{f}}\left(\varepsilon^{i r}\right)$ の中間し か取れないので、前者を lower bound、後 者を upper bound とも呼ぶ。
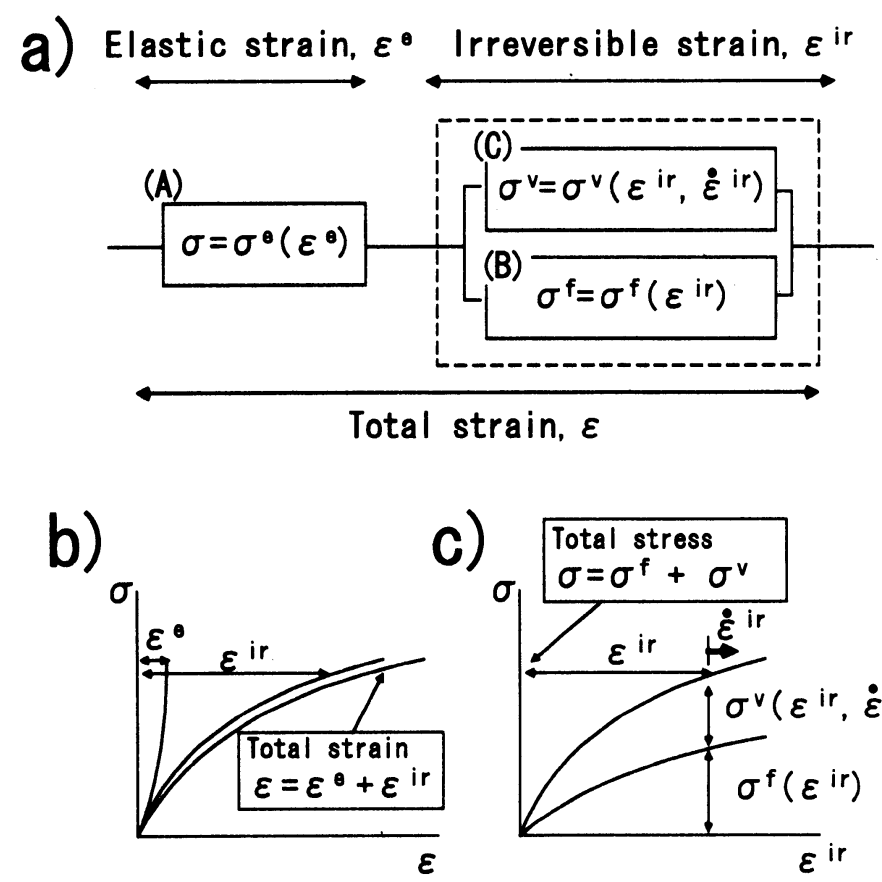

図 5 Isotach モデルの概念図

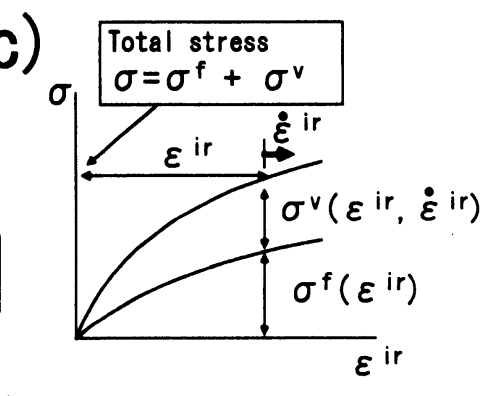

a ) 3 要素の応力、ひずみ、ひずみ速度の依存関係と構成

b ）全ひずみの弾性ひずみと不可逆ひずみへの分割

c）応力の不可逆ひずみ速度依存・非依存部分への分配 
New Isotach モデルでは、クリープ変形時の挙動は次のように求められる。図 6 a で、一定のクリー プ荷重 $\sigma_{\text {creep }}$ の下で、現在の不可逆ひずみが $\varepsilon^{i r}$ であるとする。このときの不可逆ひずみ速度非依存の応 力成分 $\sigma^{\mathrm{f}}$ はモデルで与えられた関数 $\sigma^{\mathrm{f}}\left(\boldsymbol{\varepsilon}^{\mathrm{ir}}\right)$ で求められる。従って、不可逆ひずみ速度依存の応力成分 は $\sigma^{\mathrm{v}}\left(\varepsilon^{i r}, \dot{\varepsilon}^{i r}\right)=\sigma_{\text {creep }}-\sigma^{\mathrm{f}}\left(\varepsilon^{i r}\right)$ で求められ、式 4 から $\mathrm{g}_{\mathrm{v}}\left(\dot{\varepsilon}^{i r}\right)$ の值、従って $\dot{\varepsilon}^{i r}$ が順次逆算でき る。クリープが進むと、応力・ひずみ状態は lower bound に近づいていき、無限の時間の後にこの曲 線上に達してそれ以上はクリープしない。

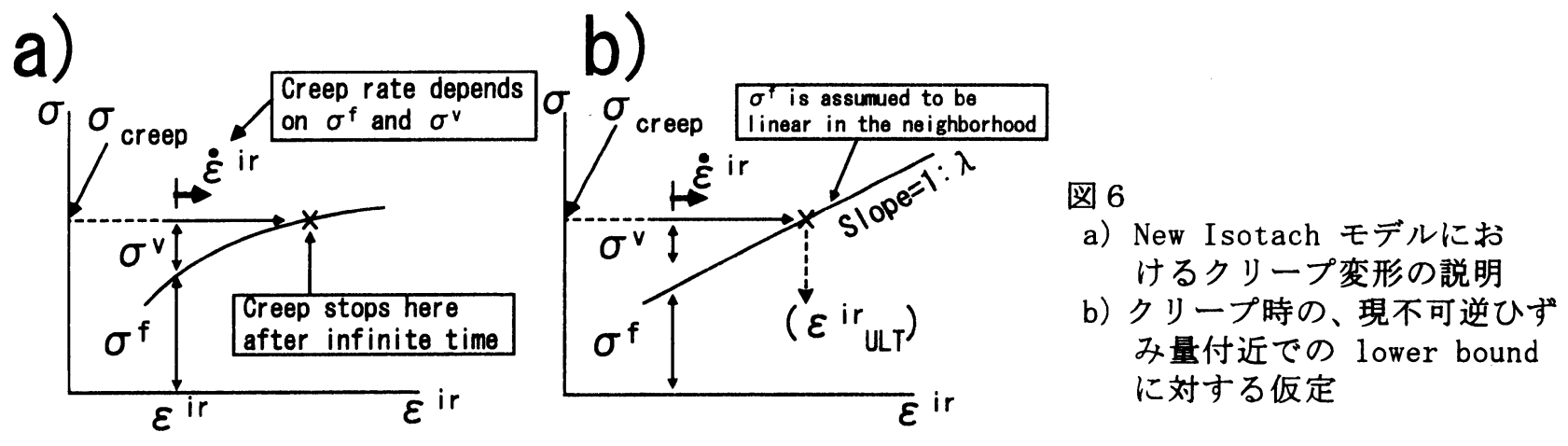

\section{2 弾性要素のパラメータの推定}

P L・P S 橋脚で測定された全ひずみを、弾性成 分と非可逆成分に分割するために、式 2 に現れるパ ラメータを推定する。図 $7 \mathrm{a}$ は、P L・P S 橋脚の 盛土材と同じ粒度調整砕石を締固めた供試体を用い た、有効側圧一定の室内中型三軸圧縮試験で得られ た、偏差応力と軸ひずみである。供試体は $30 \mathrm{~cm} \mathrm{x} 30 \mathrm{~cm}$ x $60 \mathrm{cmH}$ の直方体で、ひずみは LDT を用いて精密に 計測した。供試体は湿潤単体重量 $2.2 \mathrm{kN} / \mathrm{m}^{3}$ (含水 比3.0\%）で、非常によく締まっている。実施工の $\mathrm{P}$ $\mathrm{L} \cdot \mathrm{P} \mathrm{S}$ 橋脚の単体重量も同程度と仮定して、この 三軸試験結果を用いてモデルのパラメータを推定し た。この試験では、図 7 a に示すように、両振幅で 約 $10 \mathrm{kPa}$ の微少な繰返し載荷を様々な応カレベルで 行い、それぞれのヤング率を測定している。そのヤ ング率と軸圧縮応力との関係を図 $7 \mathrm{~b}$ のように両対 数でプロットし、直線近似することによって、

$\sigma_{0}=100 \mathrm{kPa}, \mathrm{E}_{0}=610 \mathrm{MPa}, \mathrm{m}=0.63$

を得た。これを用いて各応力レベルでの弾性ひずみ $\varepsilon^{\mathrm{e}}$ を求め、それと全ひずみ $\varepsilon_{\mathrm{total}}$ との差として非可 逆ひずみ $\varepsilon$ ir 求めたものを、図 $7 \mathrm{a}$ に重ねて示す。

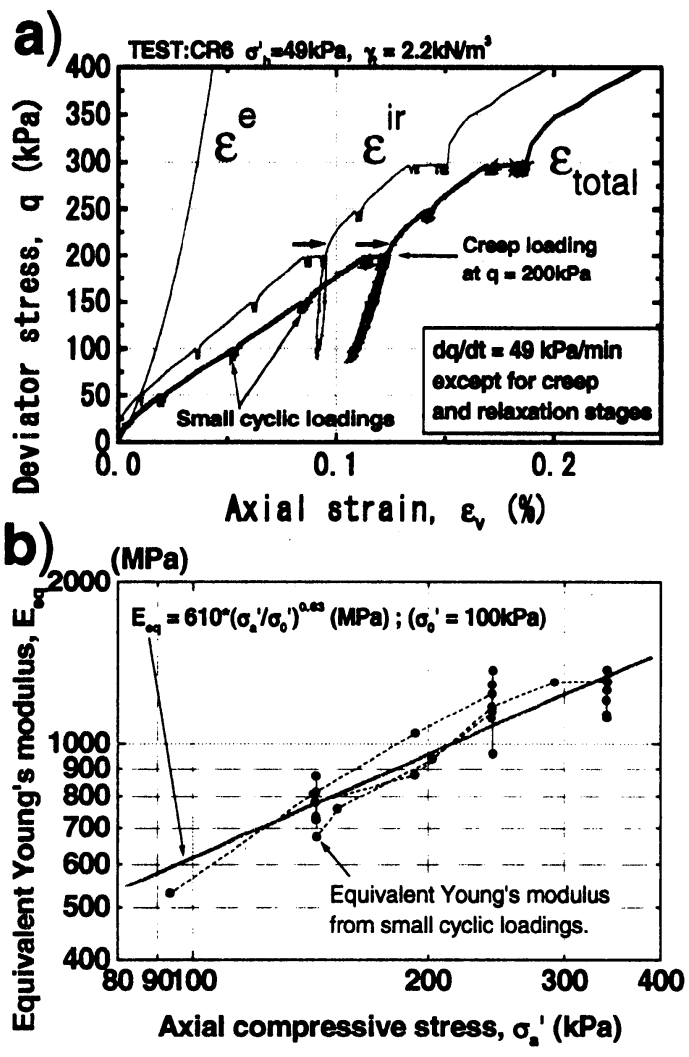

図 $7 \quad$ P L ・P S 橋脚の盛土材の三軸試験

a ）偏差応力・軸圧縮ひずみの関係

b ）軸圧縮応力・ヤング率の関倸 


\section{3 不可逆ひずみ速度依存性のパラメータの推定}

式 4 の $\mathrm{g}_{\mathrm{v}}\left(\dot{\varepsilon}^{i r}\right)$ の定義式に現れるパラメータ $\alpha 、 m 、$ $\dot{\varepsilon}_{r e f}^{i r}$ を推定する。図 7 の盛土材の三軸圧縮試験では、い くつかの応カレベルで、それぞれ約 1 時間のクリープ载 荷試験を行った。そのうち、偏差応力 $\mathrm{q}=200 \mathrm{kPa}$ でのク リープ時の挙動を図 8 に示す。図 $8 \mathrm{c}$ の不可逆ひずみ速 度は、図 $8 \mathrm{~b}$ の不可逆ひずみの時刻歴から、ひずみ増分 を時間増分で割って求めた。図 $8 \mathrm{~d}$ は、不可逆ひずみ速 度を、不可逆ひずみに対してプロットしている。

式 4 を変形して、 $\dot{\varepsilon}^{i r}$ について解くと、

$$
\left.\dot{\varepsilon}^{i r}=\dot{\varepsilon}_{r e f}^{i r}\left[\left\{1-\ln \left(1-\frac{x}{\alpha}\right)\right\}^{1 / m}\right\}-1\right]
$$

となる。ただし、 $x=g_{v}\left(\dot{\varepsilon}^{i r}\right)=\frac{\sigma_{\text {creep }}}{\sigma^{f}\left(\varepsilon^{i r}\right)}-1$ である。

この式を $\varepsilon^{i r}$ から $\dot{\varepsilon}^{i r}$ への関数を見なすとき、未知のパラ メータは、 $\alpha 、 m 、 \dot{\varepsilon}_{\text {ref }}^{i r} \sigma^{f}\left(\varepsilon^{i r}\right)$ のつである。ただ

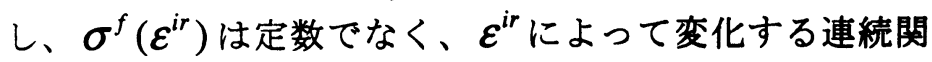
数であるから、 $\sigma^{f}\left(\varepsilon^{i r}\right)$ の関数型を指定しなければ最小 二乗法によるパラメータの決定はできない。そこで、 $\sigma^{f}\left(\varepsilon^{i r}\right)$ の関数型について、「各々のクリープ載荷時に
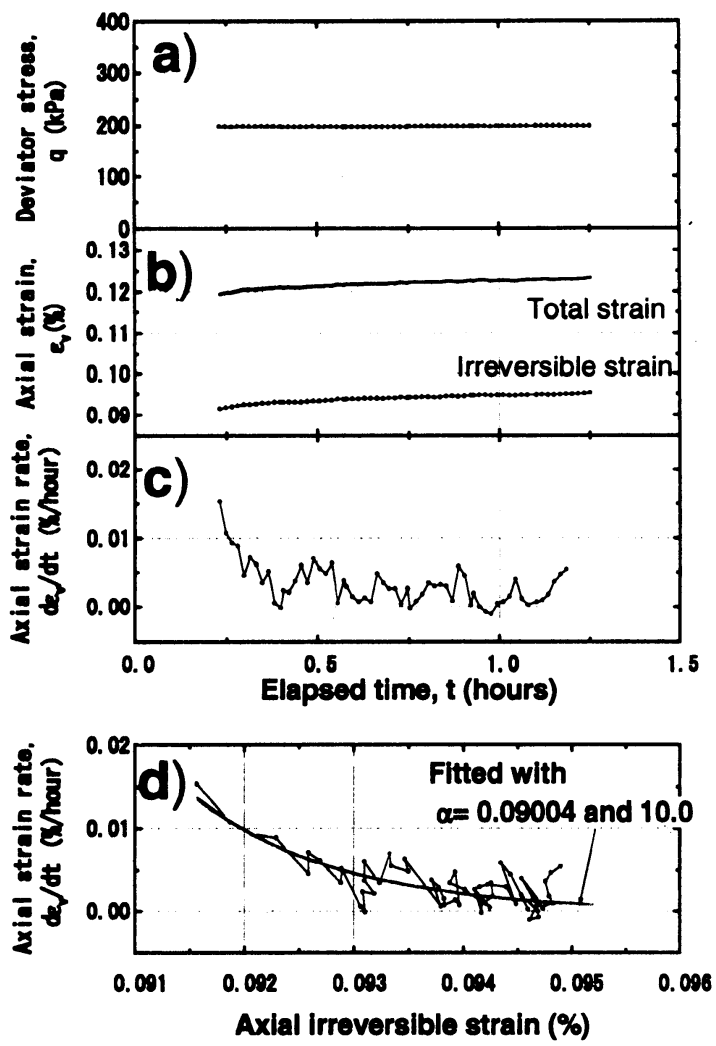

図 8 盛土材の三軸クリープ試験時の挙動 a) 偏差応力 (クリープ荷重 $\mathrm{q}=200 \mathrm{kPa}$ ) b）全軸圧縮ひずみと、その不可逆成分 c）不可逆ひずみ速度の時刻歴

d）不可逆ひずみと不可逆ひずみ速度の関係 おけるの $\varepsilon^{i r}$ の近傍では、 $\sigma^{f}\left(\varepsilon^{i r}\right)$ の形をそれぞれ直線で近似できる」と仮定し、図 $6 \mathrm{~b}$ のように、クリ

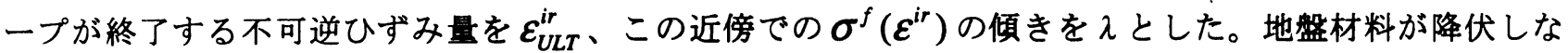
い範囲では、 $\sigma^{f}\left(\varepsilon^{i r}\right)$ が急激に折れ曲がることはなく滑らかな形をしているのが一般的なので、妥当な 仮定だと考えられる。このとき、

$$
x=g_{\nu}\left(\dot{\varepsilon}^{i r}\right)=\frac{\sigma_{\text {creep }}}{\sigma^{f}\left(\varepsilon^{i r}\right)}-1=\frac{\lambda \cdot\left(\varepsilon_{U L T}^{i r}-\varepsilon^{i r}\right)}{\sigma_{\text {creep }}-\lambda \cdot\left(\varepsilon_{U L T}^{i r}-\varepsilon^{i r}\right)}
$$

となるので、式 7 を式 6 に代入した式（5つの未知パラメータ $\alpha 、 m 、 \dot{\varepsilon}_{r e f}^{i r} \lambda \lambda 、 \varepsilon_{U L T}^{i r}$ を持つ）を用い て、図8dのプロットに対してフィッティングを行った。

原理的には、図 $8 \mathrm{~b}$ や $\mathrm{c}$ のうな非可逆ひずみや非可逆ひずみ速度の時刻歴に対してフィッティング を行うことも考えられる。しかし、式 4 を変形して時間の変数を含む式を得るためには、 $\sigma^{f}\left(\varepsilon^{i r}\right)$ の逆 数をひずみで積分する操作が必要であり、式 4 のように複雑な関数が含まれる場合には、フィッティン グに用いる式の形を求めることは非常に困難である。

フィッティングの結果、表 1 のように複数の $\alpha$ に対して最適なパラメータの組が得られることが分か った。図 $8 \mathrm{~d} に 、 こ れ ら の$ 組合せのうち、 $\alpha=0.09004$ と $\alpha=10$ の場合のパラメータを用いて得られた 曲線を示す。パラメータが全て異なっているにもかかわらず、曲線は全く一致している。その他、表 1 
に示したどの組み合わせについても、曲線は一致した。おそらく、 $\alpha$ が連続的に変化しても、各 $\alpha$ に対 して最適なパラメータの組が得られて、同一の曲線が得られるのではないかと思われる。本来、パラメ 一タが互いに独立であれば、異なるパラメータに対して同一の曲線が得られることはあり得ない。この 一つの理由として、図 $8 \mathrm{~d}$ でフィッティングに用いた点の $\varepsilon^{i r}$ 範囲が限定されれていることが考えられ る。また、式が複雑なのでパラメータに攵長性が隠されている可能性もあり、今後検討が必要である。 今回は、次の節で述べる理由もあり、 $\alpha=15$ の場合のパラメータを用いた。

表 1 不可逆ひずみ速度依存性のパラメータの推定結果

\begin{tabular}{|c|c|c|c|c|}
\hline$\alpha$ & $m$ & $\varepsilon_{\text {ref }}^{\prime}$ & $\lambda$ & $\mathcal{E}_{\text {uIT }}^{\prime \prime}$ \\
\hline 0.09004 & 0.0137 & 0.000224188 & 226.934 & 0.09716 \\
\hline 0.5 & 0.00589 & 0.000090750 & 518.0 & 0.09861 \\
\hline 1 & 0.00414 & 0.000072450 & 726.5 & 0.09889 \\
\hline 5 & 0.00194 & 0.000029659 & 1623.6 & 0.10022 \\
\hline 10 & 0.0015 & 0.000018106 & 2351.8 & 0.10118 \\
\hline 15 & 0.0013 & 0.000015034 & 2898.8 & 0.10168 \\
\hline
\end{tabular}

3.4 不可逆ひずみ速度非依存性のパラメータ(lower bound) の推定

図 3 のプレロード時の荷重・圧縮関係を、応力・ひずみ（断面積 $22.04 \mathrm{~m}^{2} 、$ 高さ $2400 \mathrm{~mm}$ ）になおして、 さらに応力については盛土全体の代表値として盛土の中間の高さでの応力を用い、ひずみについては推 定された弾性要素のパラメータを用いて弾性ひずみと不可逆ひずみに分離すると、図 9 に示すようにな る。ただし、図 9 では 1 日目の段階載荷のプレロードの部分（最初の除荷を行うまで）を拡大表示して いる。図 $8 \mathrm{~d}$ と同様に、不可逆ひずみと不可逆ひずみ速度の関係をプロットしたものを、併せて示して いる。計測間隔が 2 分に 1 回であり、データの数が少なくバラツキも大きいが、各荷重段階でのクリー プごとに、式 6 , 式 7 をフィッティングした。ただし、前節で求めたパラメータのうち、 $\alpha=15 、 m=0.0013 、$ $\dot{\varepsilon}_{r e f}^{i r}=0.000015034$ は固定して、lower bound を決めるれと $\varepsilon_{U L T}^{i r}$ だけを変えて最適化した。これで得ら れる $\varepsilon_{U L T}^{i r}$ は、各荷重段階でのクリープが、非常に長い時間の後にどこまで進むかを表す。このクリー プ終了点を図 9 にメ印で示した。これらの点を通るように、lower bound の関数を次のように決めた。

$$
\sigma^{f}\left(\varepsilon^{i r}\right)=\left(35.48+817.1 \varepsilon^{i r}\right) /\left(1+3.791 \varepsilon^{i r}\right)
$$

ここでは、表 1 のパラメータの組合わせのうち $\alpha=15$ のものを用いたが、 $\alpha=0.09004$ および $\alpha=10$ を 用いた場合の $\lambda$ と $\varepsilon_{U L T}^{i r}$ も求めて、図 10 に示す。 $\lambda$ と $\varepsilon_{U L T}^{i r}$ は、各々の荷重段階でのlower bound の傾き 上不可逆ひずみ量を個別に求めたが、 $\alpha=15$ の場合には、各点から傾き $\lambda$ でのばした矢印が全体のlower round の方向に沿っているので、互いに整合の取れた結果だといえる。これは $\alpha=10$ でも同様で、どち 、のパラメータの組合せを選ぶべきかは判断しかねる。しかし $\alpha=0.09004$ の場合には明らかに他の点 との整合が取れず、明らかに不適切なパラメータだといえる。このように lower bound 全体の整合性 に、上って、表 1 からパラメータをある程度絞ることができる。また、図 10 の A で示したように、プレ ロ - ド後に A の応力まで除荷して翌朝までプレストレス状態においたとき、弾性余効で盛土が鉛直方向 に膨張していることから、lower bound はこの応力より上を通らなければならない。表 1 でも分かるよ うに、 $\alpha$ が大きいほど lower bound は低くなるので、この点からもパラメータの範囲が絞られる。 


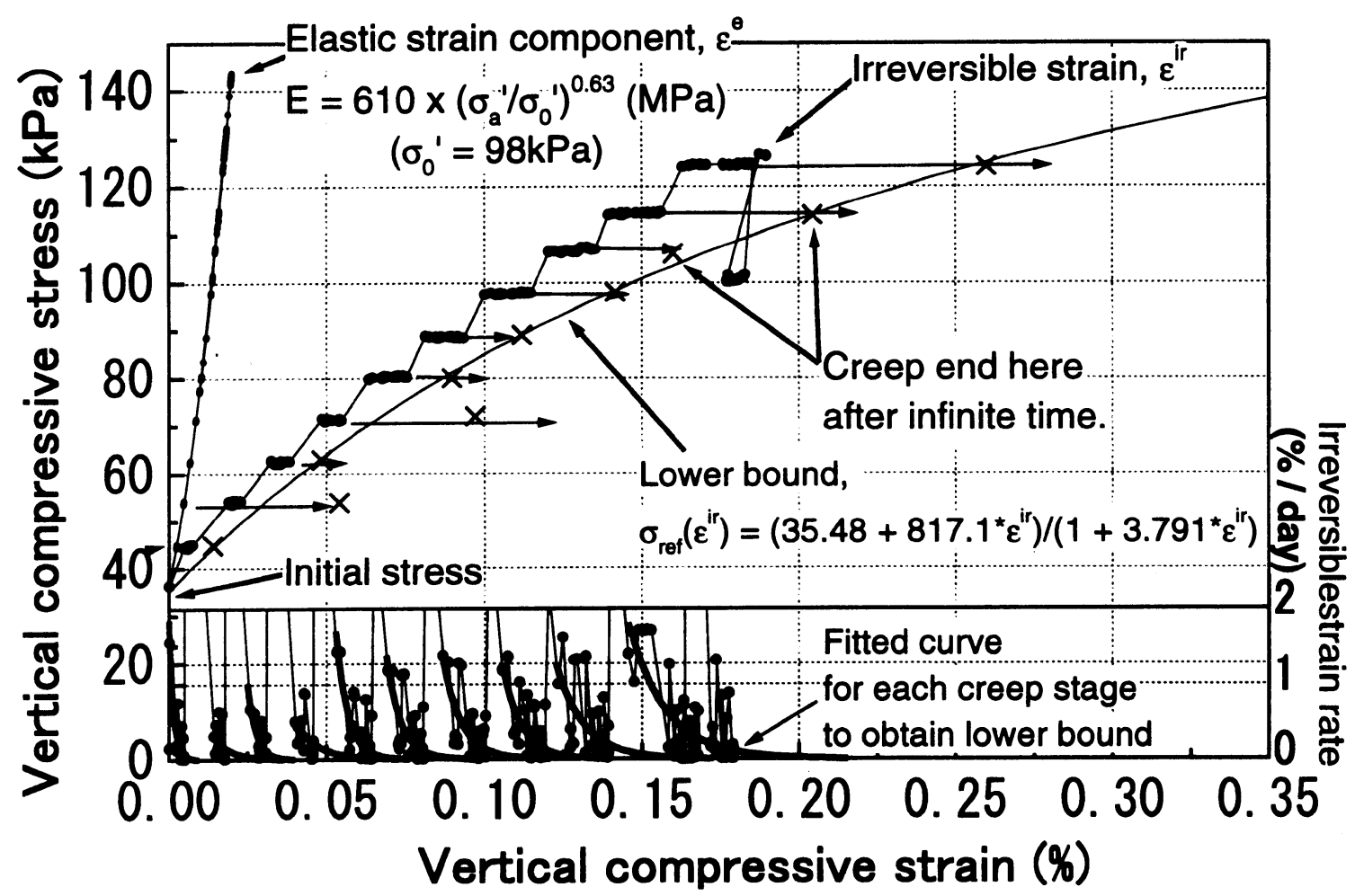

図 9 P L・P S 橋脚のプレロード载荷時の挙動に対するフィッティングで得られた lower bound

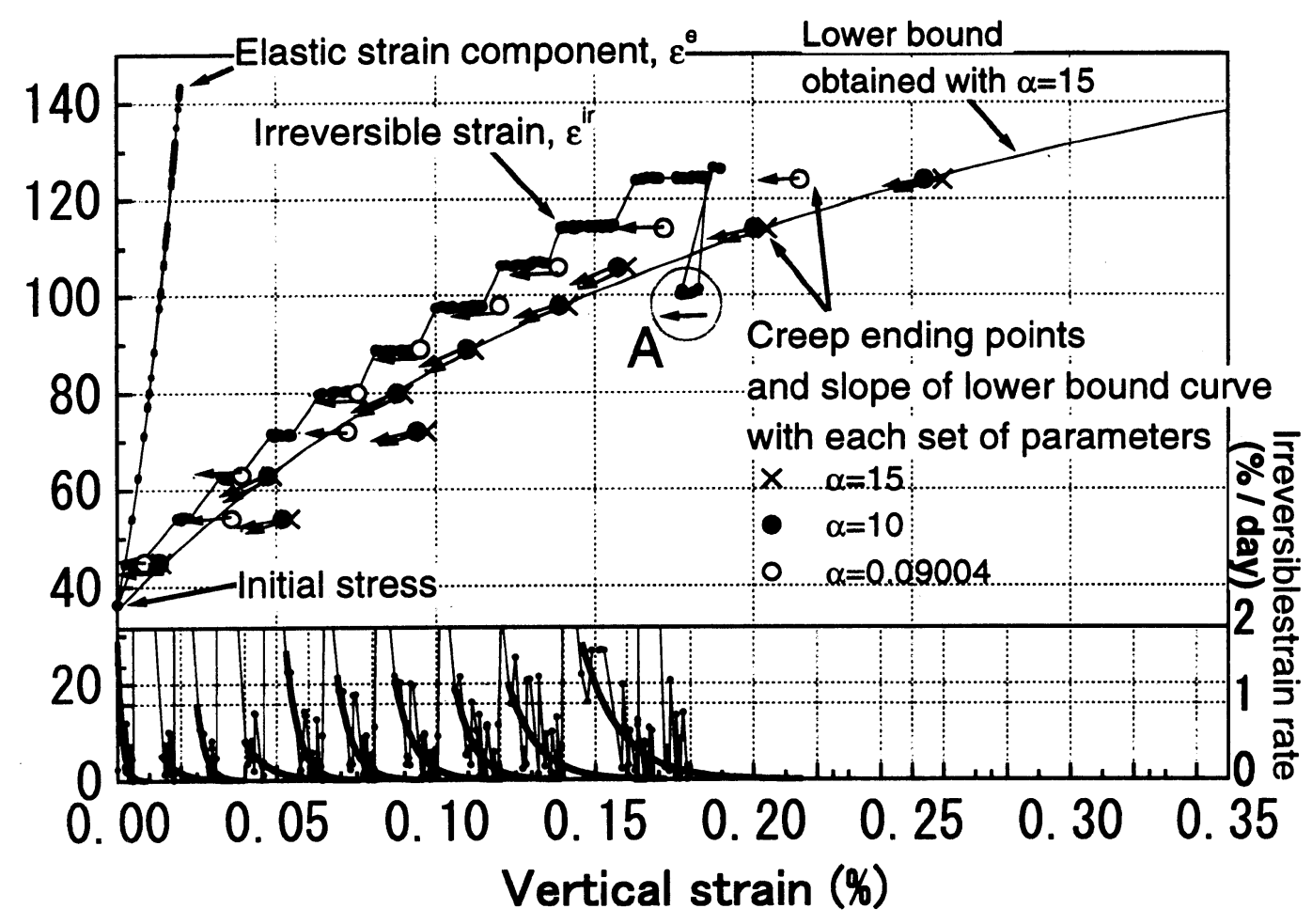

図 10 異なるパラメータを用いたときの lower bound の比較（矢印は傾き $\lambda$ の方向） 
これまでに得られたパラメータを用いて、プレロードの段階载荷時の挙動を計算したのが、図 11 で ある。計算では、実測データから得られた時間と応力を与えて、それぞれの点におけるひずみ量をモデ ルを用いて求めていく、という方法を用いた。その結果、全体として盛土の圧縮量が過大に予測されて いるが、各荷重段階でのクリープ量はほほ実測と 一致しており、次の荷重段階に進むときの圧縮量 が過大に見積もられている。これは、計測の間隔 が 2 分に 1 回であり、荷重を増加させる途中のデ 一タが与えられてないために、誤差が生じたから かも知れない。

\section{4. まとめ}

実施工の P L ・ P S 補強土橋脚は、建設から 4 年経過した現在も、大きな圧縮変形を起こさず非 常に高い長期安定性を示している。橋脚盛土のプ

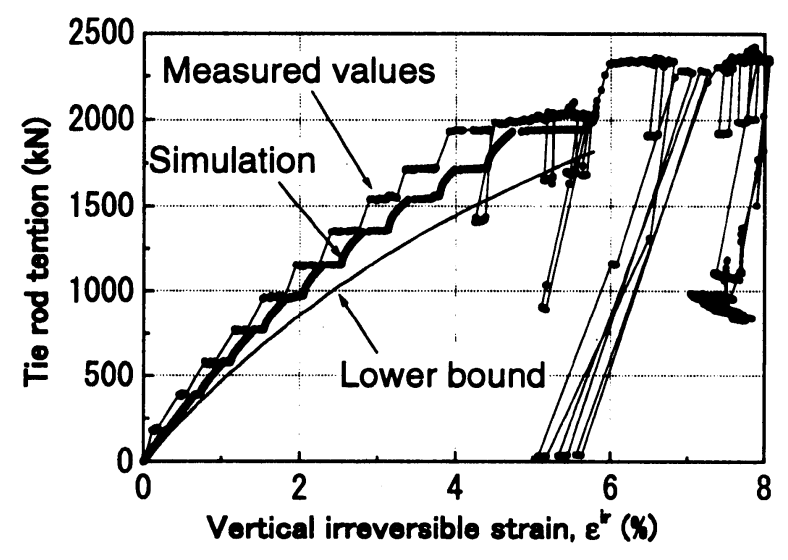

図 11 P L・P S 橋脚の挙動のシミュレーション レロード時の挙動を、New Isotach モデルを用いておおよそ正確に説明することができた。ただし、今 回用いたモデルでは、次の条件が無視されており、今後の検討が必要である。

・モデルは 1 次元で、水平ひずみの影響、特に補強材の時間効果を含む変形特性を考慮していない。

・盛土材が、真に New Isotach 則に従うのか、確認する必要がある。

・P L・P S 工法では、プレロード後に除荷する事に重要な意味があり、除荷とその後の時間効果を扱 えるモデルが必要である。

・プレロードに較べて微少ではあるが非常に多数回繰り返される交通荷重の影響を、別途モデル化しな ければならない。

謝 辞: 本報で紹介した実施工のP L・P S 補強土橋脚および補強土橋台の建設と計測では、九州旅客 鉄道株式会社に多大な協力を戴いています。厚く御礼申し上げます。

\section{参考文献}

1) 内村太郎・龍岡文夫·舘山勝・古関潤一・前田崇・鶴英樹(1996): プレローディド・プレストレスト補強盛 土のメカニズム・原理実験・実大模型実験・実施工,第 11 回ジオシンセティックスシンポジウム発 表論文集,国際ジオセンセティックス学会日本支部,pp.72-81

2) 内村太郎・龍岡文夫・古関潤一・舘山 勝・古賀徹志(1998): プレローディド・プレストレスト補強 土の現場計測法・施工法の提案,ジオシンセティックス論文集,vol.13, I G S 日本支部,pp.75-84

3) 内村太郎・龍岡文夫・舘山 勝・古賀徹志(1999): P L ・ P S 補強盛土の長期挙動, ジオシンセティッ クス論文集, vol.14, IGS日本支部, pp.155-164.

4) 龍岡文夫・石原雅規・丸山直樹(2000):地盤材料の時間依存変形特性のモデルの構造について, 第35回 地盤工学研究発表会発表講演集, Vol.1, pp.305-306. 